\title{
Heavy Metal Speciation and Health Risk Assessment of Soil and Jute Mallow (Corchorus olitorus) Collected From a Farm Settlement in Ikorodu, Lagos, Nigeria
}

\author{
Olatunji Mojeed Makanjuola ${ }^{*}$, Babatunde Saheed Bada1, Oriyomi Olalekan Ogunbanjo ${ }^{2}$, \\ Olanrewaju Olusoji Olujimi' ${ }^{1}$, Oluseyi Adeboye Akinloye ${ }^{1}$, Moyosoluwa Odunayo Adeyemi ${ }^{3}$ \\ ${ }^{1}$ Department of Environmental management and Toxicology, Federal University of Agriculture, Abeokuta, Ogun State, Nigeria \\ ${ }^{2}$ Department of Chemical Sciences, Tai Solarin University of Education, Ijagun, Ogun State, Nigeria \\ ${ }^{3}$ Department of Geology, Crawford University, Igbesa, Ogun State, Nigeria \\ Email: *tunji.makanjuola@yahoo.com
}

How to cite this paper: Makanjuola, O.M., Bada, B.S., Ogunbanjo, O.O., Olujimi, O.O., Akinloye, O.A. and Adeyemi, M.O. (2019) Heavy Metal Speciation and Health Risk Assessment of Soil and Jute Mallow (Corchorus Olitorus) Collected From a Farm Settlement in Ikorodu, Lagos, Nigeria. Journal of Agricultural Chemistry and Environment, 8, 201-223.

https://doi.org/10.4236/jacen.2019.84016

Received: July 2, 2019

Accepted: November 26, 2019

Published: November 29, 2019

Copyright $\odot 2019$ by author(s) and Scientific Research Publishing Inc. This work is licensed under the Creative Commons Attribution International License (CC BY 4.0).

http://creativecommons.org/licenses/by/4.0/

\section{(c) (i) Open Access}

\begin{abstract}
There is an increasing global concern for adverse effects of inorganic fertilizer and pesticides applied to agricultural soils. This study investigated metal speciation in soil and health risk assessment of Jute mallow (Corchorus olitoriuos) from a farm settlement in Ikorodu, Lagos State. Soil samples were collected according to the set standard procedure, sequentially extracted and analyzed for selected heavy metals using standard methods. Results showed that chromium ( $\mathrm{Cr}$ ) was associated with reducible fraction $(\mathrm{Fe}-\mathrm{Mn})$ for top soil, while cadmium $(\mathrm{Cd})$, manganese $(\mathrm{Mn})$, and copper $(\mathrm{Cu})$; lead $(\mathrm{Pb})$ and nickel $(\mathrm{Ni})$; and $\mathrm{Cr}$ were predominantly bound to carbonate, reducible and residual mineral components respectively for sub-soil. The results of Contamination Factor (CF), Contamination Degree (CD), Pollution Load Index (PLI) and Geoaccumulation Index $\left(\mathrm{I}_{\text {geo }}\right)$ showed that the soil samples were not polluted for all the investigated metals. The Cd level in the soil (13.54 \pm $\left.1.21 \mathrm{mg} \cdot \mathrm{kg}^{-1}\right)$ and vegetables $\left(0.83 \pm 0.05 \mathrm{mg} \cdot \mathrm{kg}^{-1}\right)$ were above the USEPA critical permissible limit of $3.0 \mathrm{mg} \cdot \mathrm{kg}^{-1}$ and $0.1-1.2 \mathrm{mg} \cdot \mathrm{kg}^{-1}$ respectively. The daily intake of estimated selected heavy metals from the vegetable ranged from $8.8 \times 10^{-03}$ to $1.4 \times 10^{-02}$ for adult and $3.8 \times 10^{-03}$ to $1.1 \times 10^{-02}$ for children while the Hazard Quotient (HQ) for adults ranged from $5.4 \times 10^{-05}$ to 1.1 $\times 10^{-01}$ and that of children ranged from $8.3 \times 10^{-03}$ to $1.4 \times 10^{-02}$. The cancer risk $(\mathrm{CR})$ values of heavy metals in the soil ranged from $1.02 \times 10^{-11}$ to $9.90 \times$ $10^{-10}$ and $4.45 \times 10^{-09}$ to $8.61 \times 10^{-09}$ for children and adults respectively. The level of cancer risk was below the threshold values $\left(10^{-4}-10^{-6}\right)$ which USEPA considered as unacceptable risk. The consumption of Jute mallow grown at
\end{abstract}


Ikorodu Farm Settlement is assessed to be free of risk. Hence heavy metal analysis should be included in routine soil analysis before planting.

\section{Keywords}

Inorganic Fertilizer, Pesticides, Health Risk, Jute Mallow, Heavy Metals

\section{Introduction}

In Nigeria, the rate of increase in human population which, according to the $\mathrm{Na}$ tional Population commission, stood at 88.6 million people in 2006, (and is projected to hit 160 million within the next one decade) does not enjoy a corresponding rate of increase in food supply [1] [2]. This thus creates a huge food supply deficit among Nigerians as food demand far outstripped the level of supply, creating an immense pressure on the available food items with the attendant increases in market prices [1]. Availability of food is a major issue in food security and in order to provide for more food, more lands are cultivated and fertilizer and pesticides are increasingly used. Vegetables are part of human diet to take up a lot of essential nutrients and certain trace elements in a short period. In this situation, safety of vegetables is very important [3] [4].

Findings reveal that vegetable farmers use a wide range of pesticides at different levels to reduce losses from pests and diseases. However, despite the contribution of pesticides to agricultural production, pesticides are of major environmental concern. Many pesticides and chemicals are not biodegradable, they bioaccumulate in the food chain and detrimental to human and the ecosystem [5] [6]. The repeated applications of these agrochemicals potentially contributed to the accumulation of heavy metals in agricultural soils as some of these fertilizers and pesticides contain heavy metals such as $\mathrm{Cd}, \mathrm{Pb}, \mathrm{Zn}$ [7]. The accumulation of heavy metals in soil of the study area could either directly endanger the natural soil functions, or indirectly endanger the biosphere by bioaccumulation in the food chain, and ultimately endanger human health [8].

It is commonly acknowledged that total soil heavy-metal concentration alone is not a good measure of bioavailability and is not a very helpful tool to determine the potential risk associated with soil contamination. Therefore, chemical speciation, which plays a vital role in determining the bioavailability of toxic metal in a soil solution, is often used as a predictor of metal bioavailability to soil organisms and plants [9]. The chemical forms of the metal control its bioavailability or mobility. The exchangeable and acid extractable fractions are mobile fractions that are easily bioavailable [10]. This bioavailable metals in the soil provides rough estimate of metal uptake by plants (especially edible plants) and their risk assessment.

Heavily contaminated soils may pose long-term risks to ecosystems and human health [11] [12] [13] via the increased uptake and accumulation of heavy metals in plant tissues [14] [15] [16]. Risk assessment has emerged in recent 
years as a powerful tool in the analysis of environmental and/or occupational hazards [17] [18]. This discipline is becoming increasingly important in modern toxicological and epidemiological practice, both in terms of hazard evaluation as well as at the level of efficient disease control and prevention [19] [20] [21]. Environmental analysis has largely contributed in this direction by careful monitoring of contaminant distribution over space and time [22] [23].

Several studies recently have examined heavy-metal transfer from soil to vegetables [24] [25] [26] [27]. Many studies have also reported that the bioavailability of soil metal to vegetable is controlled by soil properties, soil metal speciation, and plant species [28] [29] [30]. However, not so much has been done on effect of fertilizer and pesticide application on redistribution and bioavailability of heavy metal in soil and vegetable and their possible associated health risk. It is on this background that this study seeks to determine effect of fertilizer and pesticide application on metal speciation in soil and vegetable and to assess the health risk of human exposure to heavy metal from soil and vegetable.

\section{Materials and Methods}

\subsection{Study Area}

This study was conducted in a farm settlement in Ikorodu, Lagos state, Nigeria. Ikorodu Farm settlement is on the designated areas for farming in Lagos State. It is located in Ikorodu, its geographical coordinates falls within $6^{\circ} 40^{\prime} 0^{\prime \prime}$ North, $3^{\circ}$ 40 '0" East. The farmers in the Settlement are into several aspects of agriculture, ranging from crops farming and animal husbandry which cut across snail farming, poultry production, piggery, grass cutter farming, Vegetable farming and others. It is bounded in the North by Agbowa-Ikosi town; in the South by Isiu town, in the East by Gberigbe town, while in the West by Ode-Remo town with considerable land mass of approximately 502 square kilometres. The map of the area was shown in Figure 1.

\subsection{Sample Collection}

Soil samples were collected randomly at $0-15$ and $15-30 \mathrm{~cm}$ depth after land clearing, before the application of fertilizer and pesticide. The sample was collected at the uphill, hill wash and valley bottom. Two (2) weeks later after fertilizer application, pesticide application soil sample was collected at the same depth. Soil and vegetable samples were collected 4 weeks after pesticide application (Table 1).

\subsection{Physicochemical Analysis of Soil Samples}

Soil $\mathrm{pH}$ was determined using $\mathrm{pH}$ meter at a ratio of 1:2.5 soil/water according to the procedure described by [31]. The soil moisture content was determined according to the procedure outlined by [32] while the cation exchange capacities of the soil samples were determined by ammonium saturation method. Organic carbon and the organic matter were determined according to the procedure 


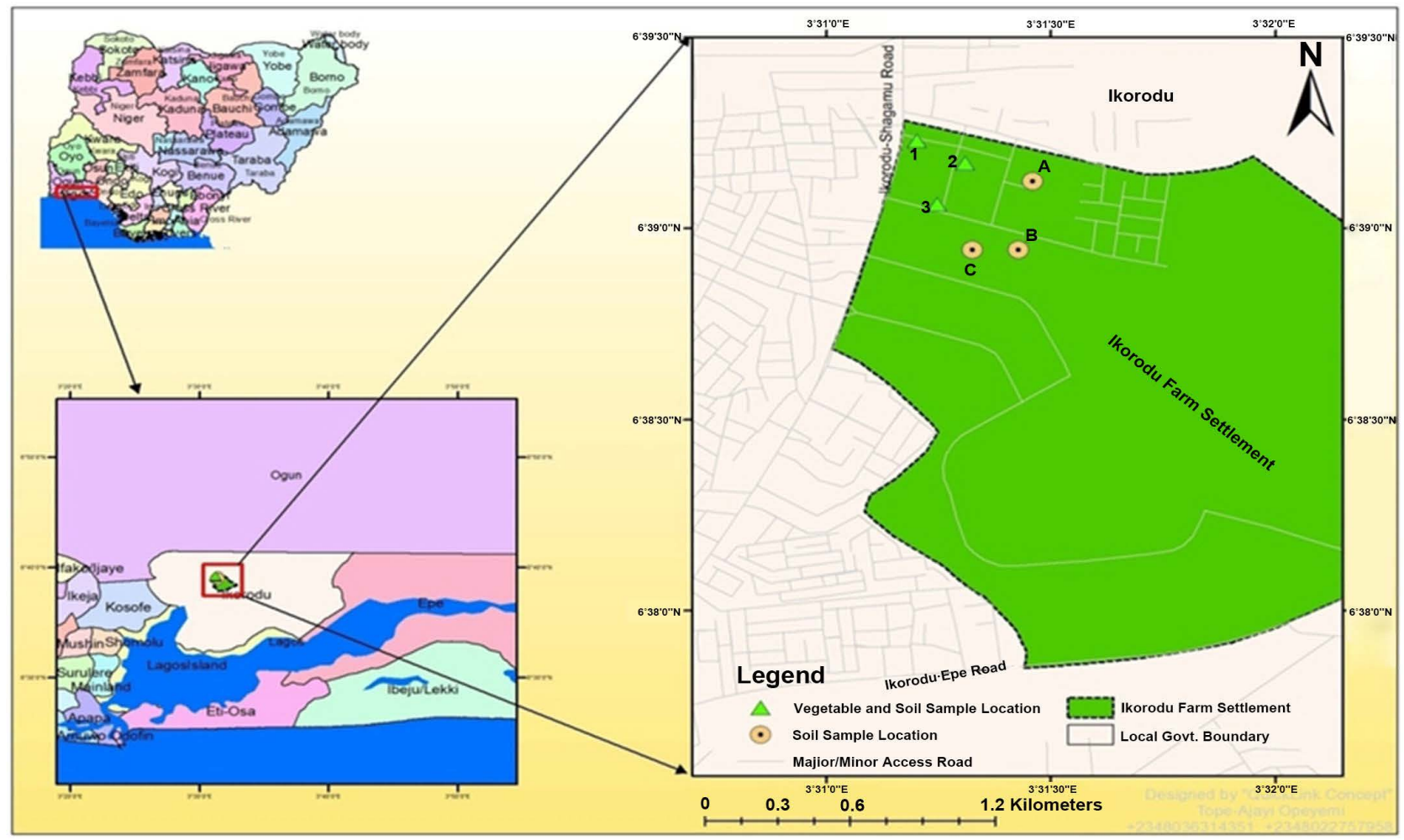

Figure 1. Map of the study area showing sampling points (field study).

Table 1. Sample collection of soil and vegetable at ikorodu farm settlement.

\begin{tabular}{ccccc}
\hline & & \multicolumn{2}{c}{ Depth/Number of Sample } & \\
\cline { 3 - 4 } & Sample & Stages of Sample Collection & $0-15$ & $15-30$ \\
\hline 1 & Soil & Immediately after land clearing & 3 & 3 \\
2 & Soil & 2 weeks after fertilizer application & 3 & 3 \\
3 & Soil and vegetable & 2 weeks after pesticide application & 3 & 3 \\
4 & Soil and vegetable & 4 weeks after pesticide application & 3 & 3 \\
\hline
\end{tabular}

outlined by [33]. Total Nitrogen was determined by the regular macro-Kjeldahl method while Phosphorus was determined according to Bray-1 method [34].

\subsection{Sequential Extraction of Heavy Metals}

A large number of sequential extraction methods have been reported, many of which are variant on Tessier procedure [35] in which the exchangeable metals and those nominally associated with different reagents. In defining the desired partitioning of metals, care was taken to choose fractions likely to be affected by various environmental conditions; the five fractions (Exchangeable, Carbonate bound, Reducible, Oxidizable, Residual) were selected in this study and this method was developed by [35] and modified by [36].

The sequential extractions were carried out on $1 \mathrm{~g}$ of soil, in $85 \mathrm{ml}$ polypropylene centrifuge tube to simplify centrifuge-washing of the residue after each ex- 
traction and to minimize contamination risks and any loss of the solids through the successive extraction steps. The sample suspensions with extractant were stirred at $220 \mathrm{~min}^{-1}$ using a Rotavit shaker (Selecta). After each extraction step, the suspensions were centrifuged at $3000 \mathrm{~min}^{-1}$ (Heraeus SAPATECH centrifuge) for $30 \mathrm{~min}$. The supernatants were carefully removed and stored in polyethylene bottles at $4^{\circ} \mathrm{C}$. The residues were washed with ultrapure water before the addition of the next extracting agent.

\subsection{Vegetable Digestion}

Digestion of the vegetable was carried out according to the method described by [37] with some modifications. Five milliliter $(5 \mathrm{ml})$ of concentrated nitric acid and five $\mathrm{ml}$ of hydrogen peroxide were added to one gram of the vegetable sample and heated on a hot plate at a temperature of $60^{\circ} \mathrm{C}$ to near dryness. Ten milliliter $(10 \mathrm{ml})$ of deionized water was then added to the mixture and then filtered. The digested sample was made up to $100 \mathrm{ml}$ and stored for analysis.

\subsection{Chemical Analysis}

The concentration of $\mathrm{Pb}, \mathrm{Cd}, \mathrm{Cu}, \mathrm{Zn}$ and $\mathrm{Fe}$ present in the soil extracts and vegetable digest were assayed using AAS (Buck Scientific Model 200 A) with air acetylene flame. The calibration of AAS was done using multi-elemental solution prepared by serial dilution of 20,10, 5, 3, 2 and $1 \mathrm{ppm}$ with $\mathrm{r}^{2}$ value above 0.9 before the analysis of the samples. As samples were aspirated into the flame, the heavy metals of interest present in the sample absorbed some of the light from the hollow cathode lamp reducing the intensity of the light transmitted. The computer data system of the machine converted the intensity of light into the absorbance which was directly proportional to the concentration of the heavy metals present in the sample. The metal concentration in $\mathrm{mg} / \mathrm{l}$ was converted to $\mathrm{mg} / \mathrm{kg}$ using the following equation:

$$
\text { Metal conc } \cdot(\mathrm{mg} / \mathrm{kg})=\frac{\text { metal conc } \cdot(\mathrm{mg} / 1) \times \text { dilution factor }(1)}{\text { mass of the sample }(\mathrm{kg})}
$$

\subsection{Data Analysis}

Descriptive (Mean and Standard deviation) and inferential (ANOVA) statistics were used. Duncan was used to compare means using statistical analysis system (SAS). The data were expressed as mean \pm standard deviation. The significant differences between groups were compared to find out the major biogeochemical processes controlling the distribution and partitioning of metals.

\subsection{Potential Human Health Risk of Metals in the Study Sites}

The health risk assessment model used in this study to calculate the exposure risk to children and Adults from heavy metals in soil is based on those models developed by [38] and the Dutch National Institute of Public Health and Environmental Protection [39] which defines guidelines or screening levels of con- 
taminants in soils in urban exposured scenarios. Human exposure to heavy metals in soil can occur via the following three main paths: a) direct ingestion of substrate dust particles $\left(C D I_{\text {ing }}\right)$; b) inhalation of suspended dust particles through mouth and nose $\left.\left(C D I_{i n h}\right) ; \mathrm{c}\right)$ dermal absorption of heavy metals in particles adhered to exposed skin $\left(C D I_{\text {dermal }}\right)$. The dose received through each of the three paths was calculated using the following Equations (2)-(4) [38] [40].

For cancer risk, only the carcinogen risk for inhalation exposure modes was considered in the model, and was used in the assessment of cancer risk [41] [42].

$$
\begin{gathered}
C D I_{\text {ing }}=C_{U C L} \times \frac{R_{\text {ing }} \times F_{\text {exp }} \times T_{\text {exp }}}{A B W \times T_{\text {avg }}} \times 10^{-6} \\
C D I_{\text {Inh }}=C_{U C L} \times \frac{R_{\text {Inh }} \times F_{\text {exp }} \times T_{\text {exp }}}{P E F \times A B W \times T_{\text {avg }}} \\
C D I_{\text {dermal }}=C_{U C L} \times \frac{S A F \times A_{\text {skin }} \times F_{\text {exp }} \times T_{\text {exp }}}{A B W \times T_{\text {avg }}}
\end{gathered}
$$

where $C D I\left(\mathrm{mg} \cdot \mathrm{kg}^{-1} \cdot \mathrm{day}^{-1}\right)$ is the Chemical daily intake through ingestion $\left(C D I_{\text {ing }}\right)$, inhalation $\left(\mathrm{CDI}_{\text {inh }}\right)$, dermal contact $\left(C D I_{\text {dermal }}\right) R_{\text {ing }}$ is the ingestion rate at $200 \mathrm{mg} \cdot$ day $^{-1}$ for children (1-6 years) and $100 \mathrm{mg} \cdot$ day $^{-1}$ for adults [43]; $R_{\text {inh }}$ is the inhalation rate at $7.6 \mathrm{~m}^{3} \cdot \mathrm{day}^{-1}$ for children and $20 \mathrm{~m}^{3} \cdot \mathrm{day}^{-1}$ for adults [42]. Exposure frequency $\left(F_{\text {exp }}\right)$ in this study was 180 day·years ${ }^{-1}$ [44] while exposure duration $\left(T_{\text {exp }}\right)$, in this study, was 6 years for children and 24 years for adults [45]. Average body weight $(A B W)$ was $15 \mathrm{~kg}$ for children and $70 \mathrm{~kg}$ for adults [43] while $P E F$ is the particle emission factor taken to be $1.36 \times 10^{9} \mathrm{~m}^{3} \cdot \mathrm{kg}^{-1}$ for both children and adults [46]. Skin surface area $\left(A_{\text {skin }}\right)$ was $2800 \mathrm{~cm}^{2}$ for children and $3300 \mathrm{~cm}^{2}$ for adults [46] and $S A F$ is the skin adherence factor given as 0.2 $\mathrm{mg} \mathrm{cm} \cdot \mathrm{h}^{-1}$ for children and $0.07 \mathrm{mg} \cdot \mathrm{cm}^{2} \cdot \mathrm{h}^{-1}$ for adults [47]. Dermal absorption factor $(D A F)$ (unitless) was 0.001 for both children and adults [48]. $T_{\text {avg }}$ is the average time [fornon-carcinogens $T_{a v g}=3659$ Texp; for carcinogens $T_{\text {avg }}=70 \times$ $365=25,550$ days [43]. $C_{U C L}$ (exposure-point upper confident limit content $\left.\left[\mathrm{mg} \cdot \mathrm{kg}^{-1}\right]\right)$ which is the upper limit of the $95 \%$ confidence interval for the mean was calculated using equation $\mathrm{v}[43]$.

$$
C_{U C L}=X+t_{1-\propto, d f} \frac{s}{\sqrt{n}}
$$

where $X$ is the arithmetic mean, $s$ is the standard deviation and $n$ is the number of samples. In this study, quantified risk or hazard indexes for both carcinogenic and non-carcinogenic effects were applied to each exposure pathway in the analysis. The chemical daily intake (CDI) for different exposure pathways was calculated for each element and subsequently divided by the corresponding reference dose yields a hazard quotient (HQ) (non-cancer risk). For carcinogens, the chemical daily intake (CDI) was multiplied by the corresponding slope factor to produce an estimate of cancer risk. Hazard index (HI) is equal to the sum of HQ. If the value of HI (non-cancer risk) is $<1$, it is believed that there is no significant risk of non-carcinogenic effects; if the value of $\mathrm{HI}>1$, there is a chance 
that non-carcinogenic effects may occur [49]. If the value of HI (cancer risk) falls within the range of threshold values $\left(10^{-4}-10^{-6}\right)$, the cancer risk is acceptable [50]. Therefore, hazard index methods and cancer risk methods were used to assess the human exposure to heavy metals in the study area.

$$
H Q=\frac{C D I_{\text {ing }}}{R f D_{o}}=\frac{C D I_{\text {dermal }}}{R f D_{o} \times G I A B S}=\frac{C D I_{\text {inh }}}{R f D_{i} \times 100 \mu \mathrm{g} / \mathrm{mg}}
$$

\subsection{Potential Daily Intake of Vegetable at the Study Site}

The methodology for the estimation of non-carcinogenic risks was provided in the USEPA Region III's Risk-based Concentration Table [51]. The non-carcinogenic risk for each individual metal through vegetables consumption were assessed by the target hazard quotient (THQ) (US Environmental Protection Agency [43], which is the ratio of a single substance exposure level over a specified time period (e.g., sub-chronic) to a reference dose $(R f D)$ for that substance derived from a similar exposure period. The equation used for estimating the target hazard quotient is as follows:

$$
D I R=C_{\text {(metal conc.) }} \times C_{(\text {factor) }} \times D_{(\text {veg intake) }}
$$

where $C_{\text {(metal conc) }}=$ heavy metal concentration in vegetable $\left(\mathrm{mg} \cdot \mathrm{kg}^{-1}\right)$;

$C_{\text {(factor) }}=$ conversion factor $(0.085)$;

$D_{\text {(vegetable intake) }}=$ Daily intake of vegetable $\left(\mathrm{kg} \cdot\right.$ person $\left.^{-1} \cdot \mathrm{day}^{-1}\right)$.

$$
T H Q=\frac{E_{f r} \times E D \times D I R}{R f D \times B W \times A T}
$$

In order to assess the overall potential for non-carcinogenic effects from more than one heavy metal, a hazard index $(H I)$ has been formulated based on the Guidelines for Health Risk assessment of Chemical Mixtures of US Environmental Protection Agency [46] as follows:

$$
H I=\sum T T H Q=T T H Q_{\text {veg } 1}+T T H Q_{\text {veg } 2}+\cdots+T T H Q_{\text {veg } n}
$$

where, $T H Q$ is the target hazard quotient; $E F r$ is the exposure frequency (365 days/year); $E D$ is the exposure duration (70 years); $C$ is the metal concentration in foods $\left(\mathrm{mg} \cdot \mathrm{kg}^{-1} \cdot \mathrm{fw}\right) ; R f D$ is the oral reference dose $\left(\mathrm{mg}^{\mathrm{kg}} \mathrm{kg}^{-1} \cdot \mathrm{day}^{-1}\right) ; A T$ is the averaging time for non-carcinogens (365 days/year $\times$ number of exposure years). The oral reference doses were based on 1.5, 0.02, 0.04, 0.0003, 0.0005, and 0.004 $\mathrm{mg} \cdot \mathrm{kg}^{-1} \cdot \mathrm{day}^{-1}$ for $\mathrm{Cr}, \mathrm{Ni}, \mathrm{Cu}, \mathrm{As}, \mathrm{Cd}$, and $\mathrm{Pb}$, respectively [51] [52]. If the $T H Q$ is less than 1 , the exposed population is unlikely to experience obvious adverse effects. If the $T H Q$ is equal to or higher than 1, there is a potential health risk and related interventions and protective measurements should be taken.

\section{Results and Discussion}

The descriptive statistics result of the physico-chemical properties at the study location is presented in Table 2 and Table 3 while the result of metal speciation of the soil for both top and sub soil for six elements and for all soil treatment is 
shown graphically in Figure 2.

The result revealed that the total extractable cadmium levels in the study area were above the critical permission of $3.0 \mathrm{mg} \cdot \mathrm{kg}^{-1}$ for agricultural soil [53] [40]. Cadmium was found to be mostly associated with the residual fraction in the top soil and carbonate fraction in the sub soil with percentage range of $34.7 \%$ to $44.9 \%$ and $33.6 \%$ to $46.2 \%$ respectively (Figure 2 ). The high percentage of Cadmium in residual fraction in the top soil shows that $\mathrm{Cd}$ is occluded in crystalline structures and has high stability. This result is in agreement with the observation of several researchers [54] [55]. By these criteria, cadmium must be considered quite mobile and biologically available in the soil samples. The availability of this metal in the sequentially extracted fractions in the top soil shows the order; Residual $(34.7 \%$ to $44.9 \%)>$ Carbonate $(23.1 \%$ to $29.8 \%)>$ Exchangeable $(3.4 \%$ to $31.5 \%)>$ Reducible $(6.51 \%$ to $20.0 \%)>$ Oxidizable (0.74\% to $1.81 \%$ ) (Figure 2 ). These extractable metals may find their way through the food chain into human body. Cadmium in the body is known to affect several enzymes [56]. It is believed that the renal damage results in proteinuriais, the result of $\mathrm{Cd}$ adversely affecting enzymes responsible for reabsorption of proteins in kidney tubules [57].

Table 2. Moisture content, $\mathrm{pH}$, electrical conductivity, organic carbon, of the farm settlement.

\begin{tabular}{ccccccc}
\hline & Sample & MC & $\mathrm{pH}$ & EC $(\mu \mathrm{s} / \mathrm{cm})$ & OC & O.M \\
\hline \multirow{2}{*}{ Land clearing } & Topsoil & $6.42 \pm 2.27 \mathrm{~b}$ & $7.06 \pm 0.05 \mathrm{a}$ & $176.2 \pm 2.00 \mathrm{~b}$ & $1.59 \pm 0.06 \mathrm{ab}$ & $3.18 \pm 0.12 \mathrm{ab}$ \\
& Subsoil & $17.53 \pm 11.1 \mathrm{a}$ & $6.75 \pm 0.26 \mathrm{bc}$ & $131.2 \pm 28.0 \mathrm{~b}$ & $1.16 \pm 0.23 \mathrm{bc}$ & $2.32 \pm 0.46 \mathrm{bc}$ \\
& Topsoil & $11.48 \pm 6.65 \mathrm{ab}$ & $7.05 \pm 0.1 \mathrm{a}$ & $162.3 \pm 6.65 \mathrm{~b}$ & $1.30 \pm 0.16 \mathrm{bc}$ & $2.60 \pm 0.33 \mathrm{bc}$ \\
\multirow{2}{*}{ Fertilizer application } & Subsoil & $7.99 \pm 3.52 \mathrm{ab}$ & $6.96 \pm 0.096 \mathrm{ab}$ & $141.3 \pm 25.1 \mathrm{~b}$ & $0.99 \pm 0.20 \mathrm{c}$ & $1.99 \pm 0.41 \mathrm{c}$ \\
& Topsoil & $9.52 \pm 2.72 \mathrm{ab}$ & $6.62 \pm 0.20 \mathrm{c}$ & $398 \pm 311 \mathrm{a}$ & $1.56 \pm 0.27 \mathrm{ab}$ & $3.11 \pm 0.55 \mathrm{ab}$ \\
Harvicide application & Subsoil & $8.95 \pm 6.46 \mathrm{ab}$ & $6.95 \pm 0.094 \mathrm{ab}$ & $167.8 \pm 58.0 \mathrm{~b}$ & $1.163 \pm 0.36 \mathrm{bc}$ & $2.33 \pm 0.73 \mathrm{bc}$ \\
& Topsoil & $10.3 \pm 1.38 \mathrm{ab}$ & $7.13 \pm 0.18 \mathrm{a}$ & $163.1 \pm 39.2 \mathrm{~b}$ & $1.91 \pm 0.37 \mathrm{a}$ & $3.82 \pm 0.74 \mathrm{a}$ \\
& Subsoil & $7.58 \pm 2.09 \mathrm{ab}$ & $6.92 \pm 0.017 \mathrm{ab}$ & $149.6 \pm 55.6 \mathrm{~b}$ & $1.57 \pm 0.255 \mathrm{ab}$ & $3.153 \pm 0.51 \mathrm{ab}$ \\
\hline
\end{tabular}

$\mathrm{MC}=$ Moisture content, $\mathrm{EC}=$ Electrical conductivity, $\mathrm{OC}=$ Organic carbon, $\mathrm{OM}=$ Organic matter. Values in the same column followed by the same superscript are not significantly $(\mathrm{P}<0.05)$ different.

Table 3. Average concentration of elements in the topsoil and subsoil from the farm settlement.

\begin{tabular}{ccccccc}
\hline & Sample & $\mathrm{P}(\mathrm{mg} / \mathrm{kg})$ & $\mathrm{Na}$ & $\mathrm{Mg}$ & $\mathrm{Ca}$ & $\mathrm{TN}$ \\
\hline \multirow{2}{*}{ Land clearing } & Topsoil & $52.38 \pm 3.00 \mathrm{a}$ & $1.20 \pm 0.20 \mathrm{a}$ & $1.03 \pm 0.42 \mathrm{ab}$ & $1.10 \pm 0.2 \mathrm{a}$ & $0.7 \pm 0.03 \mathrm{~cd}$ \\
& Subsoil & $56.03 \pm 6.07 \mathrm{a}$ & $1.07 \pm 0.21 \mathrm{ba}$ & $1.23 \pm 0.23 \mathrm{a}$ & $1.07 \pm 0.21 \mathrm{ba}$ & $0.60 \pm 0.07 \mathrm{~d}$ \\
& Topsoil & $53.3 \pm 5.41 \mathrm{a}$ & $1.10 \pm 0.2 \mathrm{ba}$ & $1.13 \pm 0.2 \mathrm{a}$ & $1.17 \pm 0.3 \mathrm{a}$ & $1.03 \pm 0.07 \mathrm{bc}$ \\
\multirow{2}{*}{ Fertilizer application } & Subsoil & $53.16 \pm 0.57 \mathrm{a}$ & $1.03 \pm 0.32 \mathrm{ab}$ & $1.13 \pm 0.45 \mathrm{a}$ & $0.97 \pm 0.35 \mathrm{a}$ & $1.04 \pm 0.23 \mathrm{bc}$ \\
& Topsoil & $52.69 \pm 3.53 \mathrm{a}$ & $0.97 \pm 0.15 \mathrm{abc}$ & $1.07 \pm 0.15 \mathrm{a}$ & $0.91 \pm 0.03 \mathrm{ab}$ & $0.91 \pm 0.10 \mathrm{bcd}$ \\
\multirow{2}{*}{ Pesticide Application } & Subsoil & $50.57 \pm 2.37 \mathrm{a}$ & $1.0 \pm 0.1 \mathrm{ab}$ & $1.0 \pm 0.26 \mathrm{ab}$ & $1.0 \pm 0.26 \mathrm{a}$ & $1.18 \pm 0.36 \mathrm{~b}$ \\
& Topsoil & $56.9 \pm 4.18 \mathrm{a}$ & $0.70 \mathrm{c} \pm 0 \mathrm{~b}$ & $0.77 \pm 0.15 \mathrm{ab}$ & $0.73 \pm 0.21 \mathrm{ab}$ & $1.62 \pm 0.36 \mathrm{a}$ \\
& Subsoil & $56.13 \pm 3.48 \mathrm{a}$ & $0.6 \pm 0.3 \mathrm{c}$ & $0.47 \pm 0.31 \mathrm{~b}$ & $0.47 \pm 0.21 \mathrm{~b}$ & $1.07 \pm 0.15 \mathrm{bc}$ \\
\hline
\end{tabular}




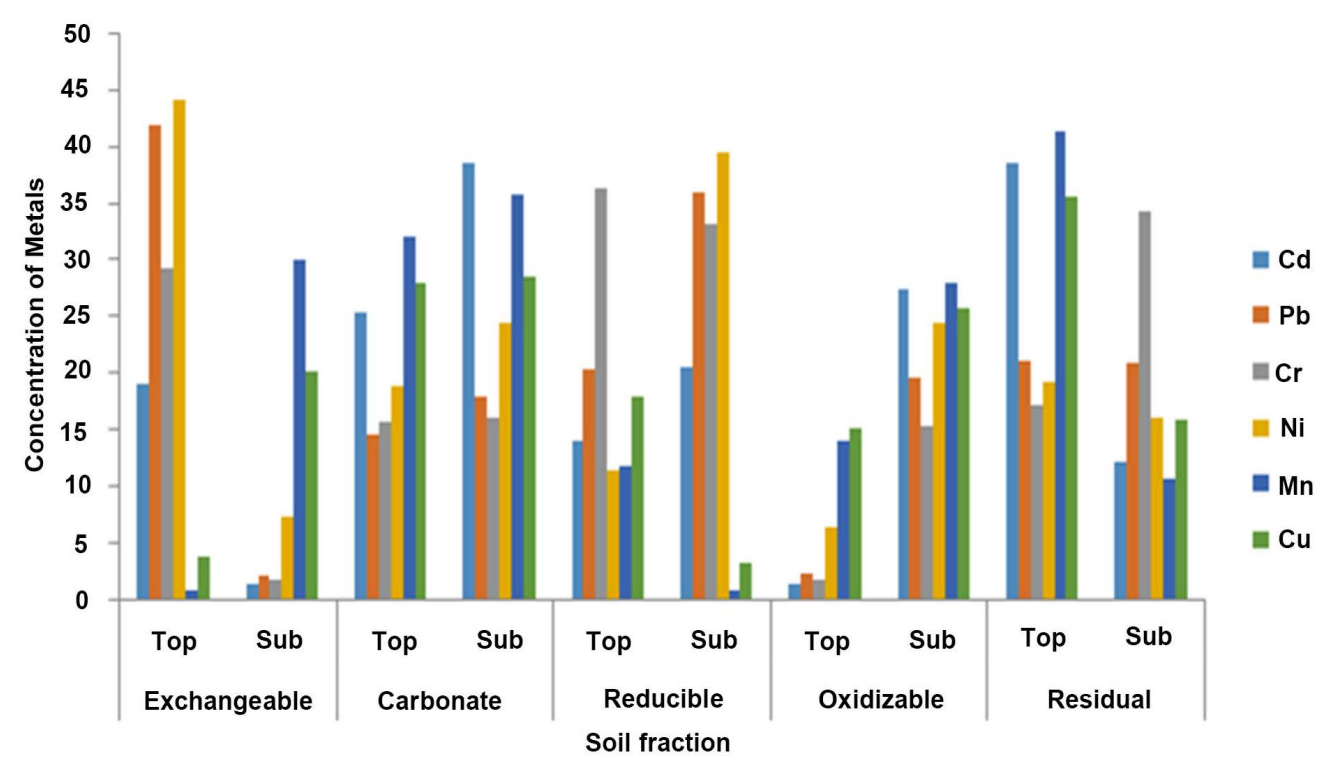

Figure 2. Percentage metals in each fraction of the soil samples.

More so, about $80 \%$ of lead was found in the non-residual fraction while high percentage of the total extractable fraction contributed to the mobile phase (exchangeable and carbonate phase) and as such implicates higher risk for lead contamination. However, total extractible $\mathrm{Pb}$ from all the sampling points in both study areas falls below $140 \mathrm{mg} \cdot \mathrm{kg}^{-1}$ set by USEPA for agricultural soil. $\mathrm{Pb}$ was found to be mostly associated with the exchangeable fraction in the top soil with percentage range of $27.6 \%$ to $44.9 \%$ (Figure 2 ). A high percentage of exchangeable $\mathrm{Pb}$ in the top soil might increase the potential of $\mathrm{Pb}$ mobility and bioavailability in these soils. The potential bioavailability of the metal in the top soil is in the following order Exchangeable (27.6\% to 53.7\%) > Reducible (16.7\% to $24.4 \%)>$ Residual $(15 \%$ to $33.7 \%$ ) Carbonate $(10.2 \%$ to $19.3 \%)>$ Oxidizable (1.26\% to $2.83 \%$ ) (Figure 2 ).

The total extractable Chromium in the soil was below $750 \mathrm{mg} \cdot \mathrm{Kg}^{-1}$ limit permissible by [58] and [59] for domestic gardens, agricultural and residential areas. The Cr content was strongly associated with the reducible fraction in the top soil with percentage range of $29.3 \%$ to $44.8 \%$. The potential bioavailability of the metal for top soil is in the following order; Reducible $(29.3 \%$ to $44.8 \%)>$ Exchangeable $(16.7 \%$ to $38.0 \%)>$ Residual $(17.2 \%$ to $18 \%)>$ Carbonate $(14 \%$ to $17.9 \%)>$ Oxidizable $(0.54 \%$ to $2.85 \%)$.

The level of Nickel in the farmland fell within the permissible limit of 150 $\mathrm{mg} \cdot \mathrm{Kg}^{-1}$ set by [59] for residential and agricultural lands. Most of the $\mathrm{Ni}$ was found in the exchangeable in the top soil with percentage range of $26.4 \%$ to $51.7 \%$ (Figure 2). High concentration of $\mathrm{Ni}$ in exchangeable fraction for top soil indicated that $\mathrm{Ni}$ was in active speciation [60], which suggests that $\mathrm{Ni}$ in these mediums has strong activity and bioavailability. This result is at variance with the work of [61] [62] [63] where they reported a high concentration of $\mathrm{Ni}$ in other soil fractions other than exchangeable fraction. The potential bioavailabil- 
ity of the metal for top is in the following order: Exchangeable $(26.4 \%$ to $51.7 \%)>$ Carbonate $(15.2 \%$ to $25.5 \%)>$ Residual $(17.9 \%$ to $22.7 \%)>$ Reducible ( $8 \%$ to $14.9 \%)>$ Oxidizable $(0.58 \%$ to $14.3 \%)$.

The concentrations of total extractible $\mathrm{Cu}$ in the farmland were all below the toxic limit of $250 \mathrm{mg} \cdot \mathrm{kg}^{-1}$ set by [64] for agricultural lands indicating that the soil is not polluted with $\mathrm{Cu}$. The results also indicated that majority of $\mathrm{Cu}$ in the top soil was associated with the residual fraction (i.e. bound to silicates and detrital materials) having a percentage range of $25.7 \%$ to $42.6 \%$ (Figure 2 ) which is similar to the reports of [65] and [36]. The result is at variant to [66] and [67] in which their findings revealed $\mathrm{Cu}$ to be mostly abundant in the oxidizable fraction. Heavy metals with high abundance in the residual phase are not easily bioavailable to the environment. The association of $\mathrm{Cu}$ with different fractions was observed to be in the order for the top soil; Residual $(25.7 \%$ to $42.6 \%)>$ Carbonate $(21.9 \%$ to $36.4 \%)>$ Reducible $(12.8 \%$ to $21.6 \%)>$ Oxidizable $(6.1 \%$ to $24.7 \%)>$ Exchangeable (1.24\% to $5.95 \%)$.

On the other hand, appreciably high amount of Cadmium found in carbonate fraction in the sub soil suggested that cadmium is potentially available to some extent in these soils because metals in this fraction are usually thought to be readily available for plants uptake. By these criteria, cadmium must be considered quite mobile and biologically available in the soil samples. The availability of this metal in the sequentially extracted fractions in the sub soil shows the order; Carbonate (33.6\% to $46.2 \%)>$ Oxidizable $(24.7 \%$ to $29.9 \%$ ) Reducible (3.8\% to $33.7 \%)>\operatorname{Re}$ sidual $(7.0 \%$ to $20.5 \%)>$ Exchangeable $(1.22 \%$ to $1.75 \%)>$ Oxidizable $(0.74 \%$ to $1.81 \%$ ) (Figure 2). Cadmium reduces the activity of delta aminolevulinic acid synthetase, arylsulfatase, alcohol dehydrogenase, and lipoamidedehydrogenase, whereas it enhances the activity of delta aminolevulinic acid dehydratase, pyruvate dehydrogenase, and pyruvate decarboxylase [68].

Lead was found to be mostly associated with the reducible fraction in the sub soil with percentage range of $15.8 \%$ to $55.4 \%$ respectively (Figure 2 ). $\mathrm{Pb}$ in reducible fraction constituted more than $32 \%$ of total concentration for all samples in the sub soil which is consistent with work of some researchers that showed reducible fraction of $\mathrm{Pb}$ to be the most important compound form in soil [60] [69] [70] [71]. Fe-Mn oxides are important scavengers of heavy metals in soils (Ping et al., 2008). This is because $\mathrm{Pb}$ element exists as $\mathrm{Pb}$ (II) in the earth's surface, which could intensely absorb on the surface of $\mathrm{Al}, \mathrm{Fe}, \mathrm{Mn}$ oxides, and silica. The potential bioavailability of the metal in the sub soil is in the following order: Reducible $(15.8 \%$ to $55.4 \%)>$ Carbonate $(14 \%$ to $55.4 \%)>$ Oxidizable $(13.9 \%$ to $28 \%)>$ Residual $(13.5 \%$ to $28 \%)>$ exchangeable $(1.13 \%$ to $3 \%)$ for sub soil respectively (Figure 2).

The Chromium content was strongly associated with the residual fractions in the sub soil with percentage range of $20.8 \%$ to $39.9 \%$ respectively (Figure 2). High concentration of residual $\mathrm{Cr}$ in the sub soil could probably be envisage because through a series of reactions in soils, $\mathrm{Cr}$ could be easily transformed into insoluble hydroxide precipitates, which stayed in the residue [71] which is in 
agreement with those reported by other researchers [15] [72] but however differ from those reported by [61] for tannery sludge. The potential bioavailability of the metal for sub soil is in the following order; Residual $(29.4 \%$ to $41 \%)>\operatorname{Re}$ ducible $(20.8 \%$ to $39.9 \%)>$ Carbonate $(13.8 \%$ to $17.5 \%)>$ Oxidizable $(14.5 \%$ to $18.1 \%)>$ exchangeable ( $1.32 \%$ to $2.58 \%$ ) in sub soil (Figure 2 ).

Most of the Nickel was found in the reducible fractions in the sub soil with percentage range $6.3 \%$ to $53 \%$ respectively (Figure 2). High concentration of Ni in the reducible fraction for both sub soil indicated that $\mathrm{Ni}$ was in active speciation [15], which suggests that $\mathrm{Ni}$ in these mediums has strong activity and bioavailability. This report is at variant to the work of [61] [62] [63] where they reported high concentration of $\mathrm{Ni}$ in other soil fractions other than reducible fraction. The potential bioavailability of the metal for sub soil is in the following order: Reducible $(6.3 \%$ to $53 \%)>$ Oxidizable $(19.1 \%$ to $33.8 \%)>$ Carbonate $(16.1 \%$ to $36.1 \%)>$ Residual $(6.9 \%$ to $26.7 \%)>$ exchangeable $(1.50 \%$ to $18.6 \%)$ in sub soil (Figure 2).

However, it was inferred from the result that majority of extractable $\mathrm{Cu}$ in the sub soil was associated with the carbonate fraction which it's potential mobility and bioavailability. The association of $\mathrm{Cu}$ with different fractions was observed to be in the order for the sub soil; Carbonate $(3.89 \%$ to $50.3 \%)>$ Oxidizable (17.6\% to $33.4 \%)>$ Exchangeable (5.45\% to $42.8 \%)>$ Residual $(11.4 \%$ to $21.9 \%)>$ Reducible (1.97\% to $4.95 \%$ ) (Figure 2 ).

The Cadmium concentration was noted above the recommended value of 3.0 $\mathrm{mg} \cdot \mathrm{kg}^{-1}$ for agricultural soil [43] [53] throughout the study area. Contamination of soil with $\mathrm{Cd}$ is increasingly becoming a major problem in developing countries worldwide. Concentration of $\mathrm{Cd}$ in Agricultural soil of south west, Nigeria ranged from 4.50 - $9.63 \mathrm{mg} \cdot \mathrm{kg}^{-1}$ [73], Peri-smelter soil in China ranged from 4.1 $167.6 \mathrm{mg} \cdot \mathrm{Kg}^{-1}[63]$; Industrial zone in North east China ranged from $0.76-81.20$ $\mathrm{mg} \cdot \mathrm{kg}^{-1}$ [74]; Dumpsites soil in Abia state, Nigeria ranged from 6.78 - 72.13 $\mathrm{mg} \cdot \mathrm{kg}^{-1}[62]$ and so on.

The Muller Index of Geoaccumulation, Igeo indicating the level of contamination found in various soils, is widely recognized in Europe. $\mathrm{I}_{\text {geo }}$ consist of seven grading ranging from unpolluted to very seriously pollute. Grade 6 indicates a 64-fold enrichment over the background values [75].

The result from the study shows that the soil was not contaminated for all the metal analyzed in the soil (Table 3). Contamination factor (CF) is used to illustrate the contamination of particular toxic substance at a given site [76]. It can be observed from the result that the soil was practically not contaminated with all the metals studied in the soil at this site. The study revealed $\mathrm{Ni}$ as the most severe component causing moderate to very high contamination of the soil in the study site. A similar pattern was noted for contamination degree (CD) (Table 4), where sampling sites having dominant anthropogenic activities displayed high CD for nickel. This demonstrates regular monitoring of the farmland for the presence of trace elements especially nickel is required. 
In geochemical investigations, PLI is used as a resourceful tool to measure and compare soil contamination. Analyzed soil at all the sampling points displayed higher PLI values for $\mathrm{Ni}$ and progressive deterioration in quality (Table 4). Higher PLI values in soil demonstrated substantial anthropogenic impacts on the soil quality whereas lower PLI values pointed to no considerable anthropogenic activities. This investigation strengthened employment of CD and PLI as effective instruments for assessing the environmental geochemistry of soil and could be used individually or in combination as they closely complemented each other. Furthermore, they easily convey information to the public and policy makers to ascertain the contamination load of the soil to take necessary remedial measures.

Heavy-metal exposure has potential and serious health risk to [77] Thus, in this study, the health risk of heavy metal exposure to humans was one of the main focus issues. The results of the carcinogenic and non-carcinogenic risk assessment for children and adults using the summation of mobile fractions are presented in (Table 5). For the non-cancer effects for adults; dermal exposure to $\mathrm{Cd}(4.28 \mathrm{E}+06)$ and ingestion route to $\mathrm{Cr}(1.01 \mathrm{E}-02)$ are the major exposure routes. The non-cancer distribution pattern for both ingestion and dermal routes was: $\mathrm{Cd}>\mathrm{Cr}>\mathrm{Ni}>\mathrm{Mn}>\mathrm{Pb}>\mathrm{Cu}$. Additionally, total exposure Hazard Index (HI) from ingestion, dermal contact, and inhalation for $\mathrm{Cd}, \mathrm{Pb}$ and $\mathrm{Mn}$ were greater for children than for adults. Children are more susceptible to a given dose of toxin and are likely to inadvertently ingest significant quantities of metals because of their hand-to-mouth behavior, which has been widely regarded as a key metal exposure pathway for children [78].

Hazard Index (HI) values for analyzed elements to both adults and children decrease in the order of $\mathrm{Mn}>\mathrm{Cd}>\mathrm{Cr}>\mathrm{Ni}>\mathrm{Pb}>\mathrm{Cu}$. The HI summation for the sites using Mobile Fractions (F1 + F2 + F3 + F4) showed that Manganese poses a higher risk of non-cancer effects among the studied elements while Copper poses the lowest (Table 5). The sum of hazard index $(\Sigma \mathrm{HI})$ for all of the metals and all routes for both adult and children is $6.15 \mathrm{E}+15$. This HI value is $>1$ and this is an indication that the soil poses non-cancer threat to human. The range reported for the non-cancer effects in the present study is at variance to the values reported by some authors [79] [80] [81], but also in agreement with [82]. Among the carcinogenic metals, only $\mathrm{Cd}, \mathrm{Pb}, \mathrm{Cr}$ and $\mathrm{Ni}$ are analyzed, and carcinogenic risk was assessed from calculated daily dose (CDI) multiplied by the corresponding SLF. The cancer risk for Children ranged from $1.02 \mathrm{E}-11$ to $9.90 \mathrm{E}-10$ and that of the Adult ranged from $4.45 \mathrm{E}-09$ to $8.61 \mathrm{E}-09$ respectively. The level of cancer risk for $\mathrm{Cd}, \mathrm{Pb} \mathrm{Cr}$ and $\mathrm{Ni}$ falls below the threshold values $\left(10^{-4}\right.$ to $\left.10^{-6}\right)$ which some environmental and regulatory agencies considered as unacceptable risk. It is noteworthy that the $\Sigma \mathrm{CR}$ for all the metals and routes for Children (1.08E-09) and Adults $(1.32 \mathrm{E}-08)$ were lower than the $10^{-5}$ risk factor acceptable by some authorities [83]. 
Table 4. Contamination factor (CF), Degree of contamination (CD) and Pollution load index (PLI) of metals in the soil of the study site.

\begin{tabular}{|c|c|c|c|c|c|}
\hline Element & Soil (ppm) & $\mathrm{CF}$ & $\mathrm{CD}$ & PLI & Classification \\
\hline $\mathrm{Cd}$ & 10.3 & 0.11 & 0.21 & 0.001 & Low contamination Factor/Polluted \\
\hline $\mathrm{Cr}$ & 4.81 & 0.14 & 0.31 & 0.007 & Low contamination Factor/No Pollution \\
\hline $\mathrm{Ni}$ & 8.66 & 0.43 & 0.74 & 0.006 & Low contamination Factor/No Pollution \\
\hline $\mathrm{Mn}$ & 25 & 0.04 & 0.08 & 0.003 & Low contamination Factor/No Pollution \\
\hline $\mathrm{Cu}$ & 4.48 & 0.18 & 0.39 & 0.01 & Low contamination Factor/No Pollution \\
\hline
\end{tabular}

Table 5. Cancer risk and non-cancer risk of analyzed metals in the soil of the farm under study.

\begin{tabular}{|c|c|c|c|c|c|c|c|c|c|c|}
\hline Element & $\mathrm{Cd}$ & Cdcar & $\mathrm{Pb}$ & Pbcar & $\mathrm{Cr}$ & Crcar & $\mathrm{Ni}$ & Nicar & $\mathrm{Mn}$ & $\mathrm{Cu}$ \\
\hline Type of distribution & $\log N$ & & $\log N$ & & $\log N$ & & $\mathrm{~N}$ & & $\log N$ & $\log N$ \\
\hline 95\% UCL & 1.649 & 1.649 & 1.294 & 1.294 & 1.072 & 1.072 & 2.988 & 2.988 & 2.187 & 1.045 \\
\hline$R f D_{\text {ing }}$ & $1.00 \mathrm{E}-01$ & & $3.50 \mathrm{E}-03$ & & $3.00 \mathrm{E}-03$ & & $1.10 \mathrm{E}-02$ & & $1.40 \mathrm{E}-01$ & $4.00 \mathrm{E}-02$ \\
\hline$R f D_{i n h}$ & $2.0 \mathrm{E}-05$ & & & & $1.00 \mathrm{E}-01$ & & $7.66 \mathrm{E}-05$ & & $5.00 \mathrm{E}-02$ & \\
\hline$R f D_{\text {dermal }}$ & $2.50 \mathrm{E}-05$ & & $3.50 \mathrm{E}-02$ & & $7.50 \mathrm{E}-05$ & & $4.40 \mathrm{E}-04$ & & $1.40 \mathrm{E}-01$ & $4.00 \mathrm{E}-02$ \\
\hline$S F_{\text {inh }}$ & & $5.00 \mathrm{E}-01$ & & $5.00 \mathrm{E}-01$ & & $4.20 \mathrm{E}+01$ & & $8.40 \mathrm{E}-01$ & & \\
\hline \multicolumn{11}{|l|}{ Children } \\
\hline$C D I_{\text {ing }}\left(\mathrm{mg} \cdot \mathrm{kg}^{-1} \cdot \mathrm{d}^{-1}\right)$ & $9.29 \mathrm{E}+07$ & & $7.30 \mathrm{E}+00$ & & $6.04 \mathrm{E}+00$ & & $1.68 \mathrm{E}-06$ & & $1.23 \mathrm{E}-06$ & $5.89 \mathrm{E}-07$ \\
\hline$C D I_{\text {inh }}\left(\mathrm{mg} \cdot \mathrm{kg}^{-1} \cdot \mathrm{d}^{-1}\right)$ & $2.60 \mathrm{E}-11$ & & $2.04 \mathrm{E}-11$ & & $1.69 \mathrm{E}-11$ & & $4.71 \mathrm{E}-11$ & & $3.44 \mathrm{E}-11$ & $1.65 \mathrm{E}-11$ \\
\hline$C D I_{\text {dermal }}\left(\mathrm{mg} \cdot \mathrm{kg}^{-1} \cdot \mathrm{d}^{-1}\right)$ & $1.45 \mathrm{E}-02$ & & $1.13 \mathrm{E}-02$ & & $9.40 \mathrm{E}-03$ & & $2.62 \mathrm{E}-02$ & & $1.92 \mathrm{E}-02$ & $9.16 \mathrm{E}-03$ \\
\hline$H Q_{\text {ing }}$ & $9.29 \mathrm{E}+08$ & & $2.09 \mathrm{E}+03$ & & $2.01 \mathrm{E}+03$ & & $1.53 \mathrm{E}-04$ & & $8.79 \mathrm{E}-06$ & $1.47 \mathrm{E}-05$ \\
\hline$H Q_{i n h}$ & $1.30 \mathrm{E}-05$ & & & & & & $1.69 \mathrm{E}-10$ & & $6.15 \mathrm{E}+15$ & $6.88 \mathrm{E}-10$ \\
\hline$H Q_{\text {dermal }}$ & $2.32 \mathrm{E}+04$ & & $3.23 \mathrm{E}-01$ & & $9.62 \mathrm{E}+03$ & & $1.49 \mathrm{E}+03$ & & $1.37 \mathrm{E}-01$ & \\
\hline$H I=\sum H Q_{i}$ & $9.29 \mathrm{E}+08$ & & $2.09 \mathrm{E}+03$ & & $1.16 \mathrm{E}+04$ & & $1.49 \mathrm{E}+03$ & & $6.15 \mathrm{E}+15$ & $1.47 \mathrm{E}-05$ \\
\hline Cancer Risk & & $1.30 \mathrm{E}-11$ & & $1.02 \mathrm{E}-11$ & & $7.10 \mathrm{E}-11$ & & $9.90 \mathrm{E}-10$ & & \\
\hline \multicolumn{11}{|l|}{ Adult } \\
\hline$C D I_{\text {ing }}\left(\mathrm{mg} \cdot \mathrm{kg}^{-1} \cdot \mathrm{d}^{-1}\right)$ & $1.16 \mathrm{E}-06$ & & $9.12 \mathrm{E}-07$ & & $7.55 \mathrm{E}-07$ & & $2.11 \mathrm{E}-06$ & & $1.54 \mathrm{E}-06$ & $7.36 \mathrm{E}-07$ \\
\hline$C D I_{\text {inh }}\left(\mathrm{mg} \cdot \mathrm{kg}^{-1} \cdot \mathrm{d}^{-1}\right)$ & $1.71 \mathrm{E}-10$ & & $1.34 \mathrm{E}-10$ & & $1.06 \mathrm{E}-10$ & & $4.21 \mathrm{E}-10$ & & $3.08 \mathrm{E}-10$ & $1.47 \mathrm{E}-10$ \\
\hline$C D I_{\text {dermal }}\left(\mathrm{mg} \cdot \mathrm{kg}^{-1} \cdot \mathrm{d}^{-1}\right)$ & $2.68 \mathrm{E}+00$ & & $2.11 \mathrm{E}+00$ & & $1.67 \mathrm{E}+00$ & & $4.86 \mathrm{E}+00$ & & $3.56 \mathrm{E}+00$ & $1.70 \mathrm{E}+00$ \\
\hline$H Q_{\text {ing }}$ & $1.16 \mathrm{E}-03$ & & $2.61 \mathrm{E}-04$ & & $1.01 \mathrm{E}-02$ & & $4.80 \mathrm{E}-03$ & & $1.10 \mathrm{E}-05$ & $1.84 \mathrm{E}-05$ \\
\hline$H Q_{i n h}$ & $8.34 \mathrm{E}-08$ & & & & $1.06 \mathrm{E}-11$ & & $5.50 \mathrm{E}+01$ & & $6.16 \mathrm{E}-02$ & \\
\hline$H Q_{\text {dermal }}$ & $4.28 \mathrm{E}+06$ & & $6.03 \mathrm{E}+01$ & & $1.72 \mathrm{E}+06$ & & $2.75 \mathrm{E}+05$ & & $6.35 \mathrm{E}+01$ & $4.25 \mathrm{E}+01$ \\
\hline$H I=\sum H Q_{i}$ & $4.28 \mathrm{E}+06$ & & $6.03 \mathrm{E}+01$ & & $1.72 \mathrm{E}+06$ & & $2.75 \mathrm{E}+05$ & & $6.36 \mathrm{E}+01$ & $4.25 \mathrm{E}+01$ \\
\hline Cancer Risk & & $8.55 \mathrm{E}-11$ & & $6.70 \mathrm{E}-11$ & & $4.45 \mathrm{E}-09$ & & $8.61 \mathrm{E}-09$ & & \\
\hline
\end{tabular}


The estimated daily intake of metals from the Jute Mallow and the hazard quotient and hazard index for adult and children for were presented in (Table 6). Cadmium is a dangerous element because it can be absorbed via the alimentary tract; penetrate through placenta during pregnancy, and damage membranes and DNA [57]. Once in the human body, it may remain in the metabolism from 16 to 33 years and is connected to several health problems, such as renal damages and abnormal urinary excretion of proteins. Decrease in bone calcium concentrations and increase of urinary excretion of calcium have also been attributed to exposure to $\mathrm{Cd}$, eventually causing death. It also affects reproduction and endocrine systems of women [84]. Vegetables may contribute to about $70 \%$ of Cd intake by humans, varying according to the level of consumption [85].

The daily intake of $\mathrm{Cd}$ for adult ranged between $\left(0.023\right.$ and $0.026 \mathrm{mg} \cdot \mathrm{day}^{-1}$. person $\left.^{-1}\right)$ and children ranged between $\left(0.016\right.$ and $0.018 \mathrm{mg} \cdot$ day $^{-1} \cdot$ person $\left.^{-1}\right)(\mathrm{Table}$ 6) with $\mathrm{RfD}$, established to $0.001 \mathrm{mg} \cdot \mathrm{kg}^{-1}$ of body weight per day, equivalent to $0.07 \mathrm{mg}$ per day for a $70 \mathrm{~kg}$ adult [86]. The daily intake was higher than the tolerable daily intake (TDI) for the jute mallow. The toxic effects of $\mathrm{Pb}$ focus on several organs, such as liver, kidneys, spleen and lung, causing a variety of biochemical defects. The nervous system of infants and children is particularly affected by the toxicity of this Heavy metal. Adults exposed accidentally to excessive levels of $\mathrm{Pb}$ exhibit neuropathology. There is association between $\mathrm{Pb}$ in human body and the increase of blood pressure in adults [87]. Although $\mathrm{Pb}$ effects are more relevant for children, calculations for risk assessment were made for adults and children. The daily intake of $\mathrm{Pb}$ ranged from $\left(0.020-0.038 \mathrm{mg} \cdot\right.$ day $^{-1} \cdot$ person $\left.^{-1}\right)$ for adult and $\left(0.014-0.026 \mathrm{mg} \cdot \mathrm{day}^{-1}\right.$. $^{-}$erson $\left.^{-1}\right)$ for children (Table 6) which is $15.5 \%$ of $\mathrm{RfD}$ value of $0.245 \mathrm{mg}$ per day for a $70 \mathrm{~kg}$ adult. $\mathrm{Pb}$ concentrations were high in jute mallow. This value ( 0.025 and $0.521 \mathrm{mg}$ per day) was below those reported in literature [88].

$\mathrm{Cr}$ is an important element for the insulin activity and DNA transcription. However, an intake below $0.02 \mathrm{mg}$ per day could reduce cellular responses to insulin [89]. The daily intake, ranged from 0.012 to $0.023 \mathrm{mg} \cdot \mathrm{day}^{-1} \cdot$ person $^{-1}$ for adult and 0.079 to $0.099 \mathrm{mg} \cdot \mathrm{day}^{-1} \cdot$ person $^{-1}$ for children estimated, was lower than

Table 6. Daily metal intake estimate and hazard quotient for bush okra in investigating site.

\begin{tabular}{|c|c|c|c|c|c|c|c|}
\hline Element & $\mathrm{Cd}$ & $\mathrm{Pb}$ & $\mathrm{Cr}$ & $\mathrm{Ni}$ & $\mathrm{Mn}$ & $\mathrm{Cu}$ & $\mathrm{HI}$ \\
\hline UL $\left(\mathrm{mg}\right.$ day $^{-1} \cdot$ person $\left.^{-1}\right)$ & $6.4 \mathrm{E}-02$ & $2.4 \mathrm{E}-01$ & $1.05 \mathrm{E}-02$ & $1.0 \mathrm{E}-00$ & $1.1 \mathrm{E}+01$ & $1.0 \mathrm{E}+01$ & \\
\hline $\operatorname{RfDo}\left(\mathrm{mg} \cdot \mathrm{kg}^{-1} \cdot\right.$ day $\left.^{-1}\right)$ & $5.0 \mathrm{E}-04$ & $4.0 \mathrm{E}-03$ & $1.5 \mathrm{E}-00$ & $2.0 \mathrm{E}-02$ & $1.4 \mathrm{E}-02$ & $4.0 \mathrm{E}-02$ & \\
\hline \multicolumn{8}{|l|}{ Children } \\
\hline DI & $1.6 \mathrm{E}-02$ & $1.9 \mathrm{E}-02$ & $1.1 \mathrm{E}-02$ & $1.1 \mathrm{E}-02$ & $2.4 \mathrm{E}-01$ & $3.8 \mathrm{E}-02$ & \\
\hline HQ & $8.1 \mathrm{E}-02$ & $9.0 \mathrm{E}-02$ & $3.6 \mathrm{E}-03$ & $3.6 \mathrm{E}-03$ & $8.3 \mathrm{E}-03$ & $4.6 \mathrm{E}-03$ & $2.6 \mathrm{E}+00$ \\
\hline \multicolumn{8}{|l|}{ Adult } \\
\hline DI & $2.4 \mathrm{E}-02$ & $8.8 \mathrm{E}-03$ & $1.4 \mathrm{E}-02$ & $2.1 \mathrm{E}-02$ & $3.5 \mathrm{E}-01$ & $5.7 \mathrm{E}-02$ & \\
\hline HQ & $1.1 \mathrm{E}-01$ & $3.5 \mathrm{E}-02$ & $5.4 \mathrm{E}-05$ & $5.2 \mathrm{E}-03$ & $1.3 \mathrm{E}-01$ & $7.0 \mathrm{E}-03$ & $2.9 \mathrm{E}-01$ \\
\hline
\end{tabular}


the $\mathrm{RfD}$ established at $1.5 \mathrm{mg} \cdot \mathrm{kg}^{-1}$ per day (equivalent to $105 \mathrm{mg}$ per day) [51]. This value was also lower than that recommended by the US National Council [90] for $\mathrm{Cr}^{3+}$ : from 0.05 to $0.2 \mathrm{mg}$. The daily intake of $\mathrm{Cr}$ estimated in this work was under than that reported in literature, which ranges between 0.013 and 0.098 mg per day [88] [91].

$\mathrm{Ni}$ does not have a specific function in humans; however, it is a co-factor for some microbial intestine enzymes. Ni content in the adult human body should remain below $0.1 \mathrm{mg}$ per day, and excess may cause damages to DNA and cell structures [89]. The daily intake of Ni ranged from $\left(0.012-0.026 \mathrm{mg}^{- \text {day }^{-1}}\right.$.person $\left.^{-1}\right)$ for adult and $\left(0.0079-0.0099 \mathrm{mg} \cdot \mathrm{day}^{-1} \cdot\right.$ person $\left.^{-1}\right)($ Table 5) which represents approximately $40 \%$ of RfD established in $0.02 \mathrm{mg} \cdot \mathrm{kg}^{-1}$ per day, equivalent to 1.4 $\mathrm{mg}$ per day for a $70 \mathrm{~kg}$ adult [86]. The daily intake was below the TDI of $1.4 \mathrm{mg}$ per day and lower than that reported in literature ( 0.089 and $0.231 \mathrm{mg}$ per day) [88] [91]).

Copper is an essential micronutrient required in the growth of both plants and animals. In humans, it helps in the production of blood haemoglobin. In plants, $\mathrm{Cu}$ is especially important in seed production, disease resistance, and regulation of water. Copper is indeed essential, but in high doses, it can cause anaemia, liver and kidney damage, and stomach and intestinal irritation. Copper normally occurs in drinking water from $\mathrm{Cu}$ pipes, as well as from additives designed to control algal growth. The daily intake of copper ranged from (0.05$0.2 \mathrm{mg} \cdot$ day $^{-1} \cdot$ person $\left.^{-1}\right)$ for adult and $\left(0.034-0.13 \mathrm{mg} \cdot\right.$ day $^{-1} \cdot$ person $\left.^{-1}\right)$ for children of RfD established as $0.04 \mathrm{mg} \cdot \mathrm{kg}^{-1}$ per day, equivalent to $8.0 \mathrm{mg}$ per day for a 70 $\mathrm{kg}$ adult [86]. The daily intake was below the TDI of $1.4 \mathrm{mg}$ per day.

Although the HQ-based risk assessment method does not provide a quantitative estimate for the probability of an exposed population experiencing a reverse health effect, it indeed provides an indication of the risk level due to exposure to pollutants [92]. Many researchers consider the risk estimation method reliable [91] [93] [94] and it has been proven to be valid and useful. However, this HQ method considers only exposure to HMs via consumption of vegetables, without $\mathrm{HQs}$ for individual vegetables were all below 1.0 for all $\mathrm{HMs}$. $\mathrm{HQ}$ for $\mathrm{Cd}, \mathrm{Pb}, \mathrm{Cr}$, $\mathrm{Ni}, \mathrm{Mn}$ and $\mathrm{Cu}$ ranged from 0.11 to 0.13 ; from 0.0036 to 0.047 ; from $7.5 \mathrm{E}-05$ to $3.9 \mathrm{E}-05$; from $7.1 \mathrm{E}-03$ to $2.9 \mathrm{E}-03$; from $9.5 \mathrm{E}-02$ to $1.1 \mathrm{E}-01$; and from $6.1 \mathrm{E}-03$ to $2.5 \mathrm{E}-02$ (Table to $1.1 \mathrm{E}-01$ and from $4.3 \mathrm{E}-03$ to $1.6 \mathrm{E}-02$ for children. $\mathrm{Cr}$ values were lower than 0.00001 for children and adults. When the consumption habit of adults and children in the study site were analyzed, HQs for all HMs were below 1.0 (Table 6). So, the consumption of these vegetables can be considered safe with no risk to human health.

The sequence of $\mathrm{HQ}$ for adults and children followed the decrease order $\mathrm{Cd}>$ $\mathrm{Mn}>\mathrm{Pb}>\mathrm{Ni}>\mathrm{Cu}>\mathrm{Cr}($ Table 6) for adult and $\mathrm{Pb}>\mathrm{Cd}>\mathrm{Mn}>\mathrm{Cu}>\mathrm{Ni}>\mathrm{Cr}$ for children. However, the HQ for children was higher than that for adults, as verified by other researchers [95]. High $\mathrm{Pb}$ concentrations observed in many vegetables, may be attributed to crops located near roads of heavy traffic. The 
main sources of this element to humans are inhalation of airborne $\mathrm{Pb}$ from vehicle emissions and from direct atmospheric deposition on soils, water, and crops, constituting the gateway into the food chain [96]. When the hazard index exceeds 1.0, there is concern for potential health effects [95]. Even though there was no apparent risk when each metal was analyzed individually, the potential risk could be multiplied for adults from 0.079 to 0.08 ; from 0.0025 to 0.34 ; from $4.6 \mathrm{E}-05$ to $2.6 \mathrm{E}-05$; from $4.9 \mathrm{E}-03$ to $1.9 \mathrm{E}-03$; from $7.0 \mathrm{E}-02$ considering all HMs. HI for adults and children were in ranged $3.2 \mathrm{E}-01$ to $2.4 \mathrm{E}-01$ and $5.60 \mathrm{E}-01$ to $1.7 \mathrm{E}-01$, respectively (Table 6). Neither the HI suffered from ingestion of vegetables in the study site from HMs. The relative contributions of $\mathrm{Cr}$, for adult and children were minimal which may be related to the high $\mathrm{RfD}$ of $\mathrm{Cr}$ (1.5 $\mathrm{mg} \cdot \mathrm{kg}^{-1}$ per day) [95] and [94].

\section{Conclusion}

Metal speciation and health risk assessment of soil and vegetable collected from Ikorodu farm settlemen of Lagos had been carried out. The results of speciation analysis showed that $\mathrm{Pb}$ and $\mathrm{Ni}, \mathrm{Cd}, \mathrm{Mn}$ and $\mathrm{Cu}$ were predominantly associated with exchangeable and residual fractions respectively, while $\mathrm{Cr}$ was associated with reducible fractions for top soil. Also, for sub soil; $\mathrm{Cd}, \mathrm{Mn}$ and $\mathrm{Cu}, \mathrm{Pb}$ and $\mathrm{Ni}$, and $\mathrm{Cr}$ were predominantly bound to carbonate, Fe-Mn oxide and Silicate mineral components of the soil respectively. A comparison of the result of total extractible metals with standard set by USEPA reveals that $\mathrm{Pb}, \mathrm{Cr}, \mathrm{Ni}, \mathrm{Mn}$ and $\mathrm{Cu}$ were below the threshold limit in the vegetable farmland while $\mathrm{Cd}$ level was above the critical permissible limit of $3.0 \mathrm{mg} / \mathrm{kg}$ for agricultural soil and therefore portend a health risk. The result also shows that the plant species investigated (Corchorus olitorius) accumulate all metals below the threshold limit suggested by USEPA (1986) except for $\mathrm{Cd}$ and $\mathrm{Pb}$ which exhibit higher concentration above the limit of $0.3 \mathrm{mg} \cdot \mathrm{kg}^{-1}$ and $5 \mathrm{mg} \cdot \mathrm{kg}^{-1}$. The concentration of total extractible metals in farmland was also compared to some other soil around the world, even though each area has its own geochemical characteristics. The investigation revealed $\mathrm{Cd}$ as the biggest contaminant and chief cause of concern. Four soil quality indices namely; contamination factors (CF), contamination degree (CD), pollution load index (PLI) and geo-accumulation index (Igeo) were further used to determine degree of anthropogenic influence on the soil quality. From the result, it can be deduced that the soil was practically not contaminated with all metals investigated in the soil except $\mathrm{Cd}$ which has very high contamination factor (CF), contamination degree (CD), pollution load index (PLI) and geo-accumulation index (Igeo). The health risk of heavy metal exposure to humans from the soil and vegetable was also investigated. The result reveals dermal and ingestion exposure route were the major exposure routes for adult and children respectively which can also serve as exposure route for cancer development. The Hazard index value ( $\mathrm{HI}>1$ ) from the study shows that the soil poses non-cancer threat to human. The cancer risk $\mathrm{Cd}, \mathrm{Pb}, \mathrm{Cr}$ and $\mathrm{Ni}$ ranged from 
$1.02 \mathrm{E}-11$ to $9.90 \mathrm{E}-10$ and $6.70 \mathrm{E}-11$ to $8.61 \mathrm{E}-09$ for Children and Adult respectively.

The level of cancer risk of $\mathrm{Cd}, \mathrm{Pb} \mathrm{Cr}$ and $\mathrm{Ni}$ falls below the threshold values $10^{-4}$ to $10^{-6}$ which some environmental and regulatory agencies considered as unacceptable risk. $\Sigma \mathrm{CR}$ for all the metals and routes for Children (1.08E-09) and Adults (1.32E-08) were lower than the acceptable value of $10^{-5}$. The finding of this study regarding DIR, HQ and HI showed that the consumption of bush okra grown at Ikorodu farm settlement was free of risk. But the situation could however change in future depending on the dietary pattern of the consumer and the volume of contaminant added to the ecosystem. It is therefore recommended that routine monitoring of the farmland should be carried out on regular bases. Additionally, Farmer need to be educated about the dangers associated with chemical used on the farm.

\section{Conflicts of Interest}

The authors declare no conflicts of interest regarding the publication of this paper.

\section{References}

[1] Okuneye, P.A. (2010) Rising Cost of Food Prices and Food Insecurity in Nigeria and. CBN Economic and Financial Review, 39, 23-38. http://www.funaab.edu.ng/attachments/1538_Prof. Okuneye.pdf

[2] Akanni, K.A. (2013) Agricultural Price Policy, Consumer Demand and Implications for Household Food Security in Nigeria. International Journal of Food and Agricultural Economics, 2, 121-132.

[3] Liu, X.Q., Li, C. and Wang, Y.F. (2005) Bolboschoenus (Ascherson) Palla (Cyperaceae) from Pliocene of China. Journal of Integrative Plant Biology, 47, 524-529. https://doi.org/10.1111/j.1744-7909.2005.00079.x

[4] Zhou, D.M., Hao, X.Z., Wang, Y.J., Dong, Y.H. and Cang, L. (2005) Copper and Zn Uptake by Radish and Pakchoi as Affected by Application of Livestock and Poultry Manures. Chemosphere, 59, 167-175.

https://doi.org/10.1016/j.chemosphere.2004.11.008

[5] Banjo, A.D., Aina, S.A. and Rije, O.I. (2010) Farmers' Knowledge and Perception Towards Herbicides and Pesticides Usage in Fadama Area of Okun-Owa, Ogun State of Nigeria. African Journal of Basic \& Applied Sciences, 2, 188-194.

[6] Adeola, B. (2012) Perceptions of Environmental Effects of Pesticides Use in Vegetable Production by Farmers in Ogbomoso, Nigeria. Global Journal of Science Frontier Research, 12, 73-78.

[7] Huang, S.S., Liao, Q.L., Hua, M., Wu, X.M., Bi, K.S., Yan, C.Y. and Zhang, X.Y. (2007) Survey of Heavy Metal Pollution and Assessment of Agricultural Soil in Yangzhong District, Jiangsu Province, China. Chemosphere, 67, 2148-2155. https://doi.org/10.1016/j.chemosphere.2006.12.043

[8] Liu, X., Wu, J. and Xu, J. (2006) Characterizing the Risk Assessment of Heavy Metals and Sampling Uncertainty Analysis in Paddy Field by Geostatistics and GIS. Environmental Pollution, 141, 257-264. https://doi.org/10.1016/j.envpol.2005.08.048

[9] Cui, Y. and Du, X. (2011) Soil Heavy-Metal Speciation and Wheat Phytotoxicity in 
the Vicinity of an Abandoned Lead-Zinc Mine in Shangyu City, Eastern China. Environmental Earth Sciences, 62, 257-264.

https://doi.org/10.1007/s12665-010-0519-1

[10] Ilori, O.O., Baderinwa-Adejumo, A.O. and Ilori, O.J. (2012) Effect of Salt Stress on the Germination, Water Content and Seedling Growth of Zea mays L. International Journal of Water and Soil Resources Research, 3, 20-25.

[11] European Commission (2013) Soil Contamination: Impacts on Human Health. Science for Environmental Policy, Issue 5, 1-29.

[12] Pepper, I.L. (2013) The Soil Health-Human Health Nexus. Critical Reviews in Environmental Science and Technology. https://doi.org/10.1080/10643389.2012.694330

[13] Oliver, M.A. and Gregory, P.J. (2015) Soil, Food Security and Human Health: A Review. European Journal of Soil Science, 66, 257-276. https://doi.org/10.1111/ejss.12216

[14] Hu, J., Wu, F., Wu, S., Sun, X., Lin, X. and Wong, M.H. (2013) Phytoavailability and Phytovariety Codetermine the Bioaccumulation Risk of Heavy Metal from Soils, Focusing on Cd-Contaminated Vegetable Farms around the Pearl River Delta, China. Ecotoxicology and Environmental Safety, 91, 18-24.

https://doi.org/10.1016/j.ecoenv.2013.01.001

[15] Hu, W., Chen, Y., Huang, B. and Niedermann, S. (2014) Health Risk Assessment of Heavy Metals in Soils and Vegetables from a Typical Greenhouse Vegetable Production System in China. Human and Ecological Risk Assessment: An International Journal, 20, 1264-1280. https://doi.org/10.1080/10807039.2013.831267

[16] Chang, C.Y., Yu, H.Y., Chen, J.J., Li, F.B., Zhang, H.H. and Liu, C.P. (2014) Accumulation of Heavy Metals in Leaf Vegetables from Agricultural Soils and Associated Potential Health Risks in the Pearl River Delta, South China. Environmental Monitoring and Assessment, 186, 1547-1560. https://doi.org/10.1007/s10661-013-3472-0

[17] Joseph, T., Dubey, B. and McBean, E.A. (2015) Human Health Risk Assessment from Arsenic Exposures in Bangladesh. Science of the Total Environment, 527-528, 552-560. https://doi.org/10.1016/j.scitotenv.2015.05.053

[18] Kelepertzis, E. (2014) Investigating the Sources and Potential Health Risks of Environmental Contaminants in the Soils and Drinking Waters from the Rural Clusters in Thiva Area (Greece). Ecotoxicology and Environmental Safety, 100, 258-265. https://doi.org/10.1016/j.ecoenv.2013.09.030

[19] Wagner, S.E., Burch, J.B., Hussey, J., Temples, T., Bolick-Aldrich, S., Mosley-Broughton, C., Hebert, J.R., et al. (2009) Soil Zinc Content, Groundwater Usage, and Prostate Cancer Incidence in South Carolina. Cancer Causes and Control, 20, 345-353. https://doi.org/10.1007/s10552-008-9248-0

[20] Sofuoglu, S.C., Aslan, G., Inal, F. and Sofuoglu, A. (2011) An Assessment of Indoor Air Concentrations and Health Risks of Volatile Organic Compounds in Three Primary Schools. International Journal of Hygiene and Environmental Health, 214, 36-46. https://doi.org/10.1016/j.ijheh.2010.08.008

[21] Nikolaidis, C., Orfanidis, M., Hauri, D., Mylonas, S. and Constantinidis, T. (2013) Public Health Risk Assessment Associated with Heavy Metal and Arsenic Exposure near an Abandoned Mine (Kirki, Greece). International Journal of Environmental Health Research, 23, 507-519. https://doi.org/10.1080/09603123.2013.769202

[22] Reis, A.P., Patinha, C., Ferreira Da Silva, E., Sousa, A., Figueira, R., Sérgio, C. and Novais, V. (2010) Assessment of Human Exposure to Environmental Heavy Metals in Soils and Bryophytes of the Central Region of Portugal. International Journal of 
Environmental Health Research, 20, 87-113. https://doi.org/10.1080/09603120903394649

[23] Reis, A.P., Da Silva, E.F., Sousa, A.J., Patinha, C. and Fonseca, E.C. (2007) Spatial Patterns of Dispersion and Pollution Sources for Arsenic at Lousal Mine, Portugal. International Journal of Environmental Health Research, 17, 335-349. https://doi.org/10.1080/09603120701628412

[24] Akinola, M.O. and Adedeji, O.A. (2007) Assessment of Lead Concentration in Panicum Maximum Growing along the Lagos-Ibadan Expressway, Nigeria. African Journal of Science and Technology, 8, 97-102.

[25] Amusan, A.A., Bada, S.B. and Salami, A.T. (2003) Effects of Traffic Density on Heavy Metal Content of Soil and Vegetation along Roadsides in Osun State, Nigeria. West African Journal of Applied Ecology, 4, 107-114.

[26] Olukanni, D.O. and Adebiyi, S.A. (2012) Assessment of Vehicular Pollution of Road Side Soils in Ota Metropolis, Ogun State, Nigeria. IJCEE-IJENS, 12, 40-46.

[27] Adu, A.A., Aderinola, O.J. and Kusemiju, V. (2012) Heavy Metals Concentration in Garden Lettuce (Lactuca sativa L.) Grown along Badagry Expressway, Lagos, Nigeria. Transnational Journal of Science and Technology, 2, 115-130.

[28] Yadav, S.K. (2010) Heavy Metals Toxicity in Plants: An Overview on the Role of Glutathione and Phytochelatins in Heavy Metal Stress Tolerance of Plants. South African Journal of Botany, 76, 167-179. https://doi.org/10.1016/j.sajb.2009.10.007

[29] Singh, R., Gautam, N., Mishra, A. and Gupta, R. (2011) Heavy Metals and Living Systems: An Overview. Indian Journal of Pharmacology, 43, 246. https://doi.org/10.4103/0253-7613.81505

[30] Walther, C. and Gupta, D.K. (2015) Radionuclides in the Environment: Influence of Chemical Speciation and Plant Uptake on Radionuclide Migration. Springer, Berlin. https://doi.org/10.1007/978-3-319-22171-7

[31] Strowbel, B.W., Borggaard, O.K., Hansen, H.C.B., et al. (2005) Dissolved Organic Carbon and Decreasing $\mathrm{pH}$ Mobilize Cadmium and Copper in Soil. European Journal of Soil Science, 56, 189-196. https://doi.org/10.1111/j.1365-2389.2004.00661.x

[32] APHA (1998) Standard Methods of Examination of Water and Waste Water. American Public Health Association, Washington DC, 138-142.

[33] Jackson, M.L. (1958) Soil Chemical Analysis. Prentice-Hall Inc., Englewood Cliffs.

[34] Álvarez, E.A., Mochón, M.C., Sánchez, J.C.J. and Rodrıguez, M.T. (2002) Heavy Metal Extractable Forms in Sludge from Wastewater Treatment Plants. Chemosphere, 47, 765-775. https://doi.org/10.1016/S0045-6535(02)00021-8

[35] Ben Mussa, S.A., Elferjani, H.S., Haroun, F.A. and Abdelnabi, F.F. (2009) Determination of Available Nitrate, Phosphate and Sulfate in Soil Samples. International Journal of Pharm Tech Research, 1, 598-604.

[36] Tessier, A., Campbell, P.G.C. and Bisson, M. (1979) Sequential Extraction Procedure for the Speciation of Particulate Trace Metals. Analytical Chemistry, 51, 844-851. https://doi.org/10.1021/ac50043a017

[37] Uba, S., Uzairu, A., Harrison, G.F.S., Balarabe, M.L. and Okunola, O.J. (2008) Assessement of Heavy Metals Bioavailability in Dumpsites of Zaira Metropolis, Nigeria. African Journal of Biotechnology, 7, 122-130.

[38] Shahidi, F., Chavan, U., Bal, A. and McKenzie, D. (1999) Chemical Composition of Beach Pea (Lathyrus maritimus L.) Plant Parts. Food Chemistry, 64, 39-44. https://doi.org/10.1016/S0308-8146(98)00097-1 
[39] USEPA (1996) Report: Recent Developments for in Situ Treatment of Metals Contaminated Soils. U.S. Environmental Protection Agency, Office of Solid Will Bete and Emergency Response.

[40] Van den Berg, R. (1995) Human Exposure to Soil Contamination: A Qualitative and Quantitative Analysis towards Proposals for Human Toxicological Intervention Values. RIVM Report No. 725201011. National Institute of Public Health and Environmental Protection (RIVM), Bilthoven.

[41] USEPA (1986) Test Methods of Evaluation of Solid Waste: Physical/Chemical Methods. https://www.epa.gov/epaoswer/hazwaste/test/7_series.htm

[42] Zheng, N., Liu, J., Wang, Q. and Liang, Z. (2010) Health Risk Assessment of Heavy Metal Exposure to Street Dust in the Zinc Smelting District, Northeast of China. Science of the Total Environment, 408, 726-733. https://doi.org/10.1016/j.scitotenv.2009.10.075

[43] Kurt-Karakus, P.B. (2012) Determination of Heavy Metals in Indoor Dust from Istanbul, Turkey: Estimation of the Health Risk. Environment International, 50, 47-55. https://doi.org/10.1016/j.envint.2012.09.011

[44] Visser, W.J. (1993) Contaminated Land Policies in Some Industrialized Countries. Technical Soil Protection Committee.

[45] Liu, J., Zhang, X.H., Tran, H., Wang, D.Q. and Zhu, Y.N. (2011) Heavy Metal Contamination and Risk Assessment in Water, Paddy Soil, and Rice around an Electroplating Plant. Environmental Science and Pollution Research, 18, 1623-1632. https://doi.org/10.1007/s11356-011-0523-3

[46] USEPA (2007) Guidance for Evaluating the Oral Bioavailability of Metals in Soils for Use in Human Health Risk Assessment. OSWER 9285, 7-80.

[47] USEPA (2009) Provisional Health Advisories for Perfluorooctanoic Acid (PFOA) and Perfluorooctane Sulfonate (PFOS). Office of Water, US Environmental Protection Agency, Washington, DC. https://www.epa.gov/environmental-topics/water-topics

[48] USEPA (2002) Calculating Upper Confidence Limits for Exposure Point Concentrations at Hazardous Waste Sites. Office of Emergency and Remedial Response, USEPA, Washington DC, OSWER 9285, 6-10.

[49] USEPA (2001) Supplemental Guidance for Developing Soil Screening Levels for Superfund Sites. OSWER 9355, US Environmental Protection Agency, Washington DC, 4-24.

[50] USEPA (2001) Risk Assessment Guidance for Superfund. Volume III. Part A: Process for Conducting Probabilistic Risk Assessment. EPA 540-R-02-002. USEPA, Washington DC.

[51] Ferreira-Baptista, L. and De Miguel, E. (2005) Geochemistry and Risk Assessment of Street Dust in Luanda, Angola: A Tropical Urban Environment. Atmospheric Environment, 39, 4501-4512. https://doi.org/10.1016/j.atmosenv.2005.03.026

[52] USEPA (2010) Integrated Risk Information System. http://cfpub.epa.gov/ncea/iris/compare.cfm

[53] Islam, M.S., Ahmed, M.K. and Habibullah-Al-Mamun, M. (2015) Metal Speciation in Soil and Health Risk Due to Vegetables Consumption in Bangladesh. Environmental Monitoring and Assessment, 187, 288. https://doi.org/10.1007/s10661-015-4533-3

[54] Maff (1992) Code of Good Agricultural Practice for the Protection of Soil. Welch Office Agriculture Department, Draft Consultation Document, MAFF, London, 87-153. 
[55] Ma, L. and Rao, G. (1997) Chemical Fractionation of Cadmium, Copper, Nickel, and Zinc in Contaminated Soils. Journal of Environmental Quality, 26, 259-264. https://doi.org/10.1007/s10661-015-4533-3

[56] Li, X., Poon, C.S. and Liu, P.S. (2001) Heavy Metal Contamination of Urban Soils and Street Dusts in Hong Kong. Applied Geochemistry, 16, 1361-1368. https://doi.org/10.1016/S0883-2927(01)00045-2

[57] McLaughlin, M.J., Parker, D.R. and Clarke, J.M. (1999) Metals and Micronutrients: Food Safety Issues. Field Crops Research, 60, 143-163. https://doi.org/10.1016/S0378-4290(98)00137-3

[58] Campbell, P.G.C. (2006) Cadmium: A Priority Pollutant. Environmental Chemistry, 3, 387-388. https://doi.org/10.1071/EN06075

[59] Visser, W.J.F. (1993) Contaminated Land Policies in Some Industrialized Countries. TCB Report R02, 44-88.

[60] CCME (1991) Interim Canadian Environment Quality Criteria for Contaminated Sites. Report CCME EPC-CS3.

[61] Hu, X., Zhang, Y., Luo, J., Wang, T.J., Lian, H.Z. and Ding, Z.H. (2011) Bioaccessibility and Health Risk of Arsenic, Mercury and Other Metals in Urban Street Dusts from a Mega-City, Nanjing, China. Environmental Pollution, 159, 1215-1221. https://doi.org/10.1016/j.envpol.2011.01.037

[62] Gupta, A.K. and Sinha, S. (2006) Chemical Fractionation and Heavy Metal Accumulation in the Plant of Sesamum indicum (L.) var. T55 Grown on Soil Amended with Tannery Sludge: Selection of Single Extractants. Chemosphere, 64, 161-173. https://doi.org/10.1016/j.chemosphere.2005.10.016

[63] Obasi, N.A., Akubugwo, E.I., Kalu, K.M. and Ugbogu, O.C. (2013) Speciation of Heavy Metals and Phyto-Accumulation Potentials of Selected Plants on Major Dumpsites in Umuahia, Abia State, Nigeria. International Journal of Current Biochemistry Research, 1, 16-28.

[64] Du, P., Xue, N.D., Liu, L. and Li, F.S. (2007) Distribution of Cd, Pb, Zn and Cu and Their Chemical Speciations in Soils from a Peri-Smelter Area in Northeast China. Environmental Geology, 55, 205-213. https://doi.org/10.1007/s00254-007-0976-3

[65] USEPA (1986) Test Methods for Evaluating Solid Waste: Physical/Chemical Methods. http://www.epa.gov/eposwer/hazwaste/test/7_series.htm

[66] Iwegbue, C.M., Emuh, F.N., Isirimah, N.O. and Egun, C. (2007) Fractionation, Characterization and Speciation of Heavy Metals in Composts and Compost-Amended Soils. African Journal of Biotechnology, 6, 67-78.

https://doi.org/10.1002/chin.200748228

[67] Ashraf, M.A., Maah, M.J. and Yusoff, I. (2012) Chemical Speciation and Potential Mobility of Heavy Metals in the Soil of Former Tin Mining Catchment. The Scientific World Journal, 2012, Article ID: 125608. https://doi.org/10.1100/2012/125608

[68] Kim, Y., Kim, B.K. and Kim, K. (2010) Distribution and Speciation of Heavy Metals and Their Sources in Kumho River Sediment, Korea. Environmental Earth Science, 60, 943-952. https://doi.org/10.1007/s12665-009-0230-2

[69] Manahan, S.E. (2003) Toxicological Chemistry and Biochemistry. 3rd Edition, CRC Press, Boca Raton. https://doi.org/10.1201/9781420032123

[70] Rieuwerts, J.S., Thornton, I., Farago, M.E. and Ashmore, M.R. (1998) Factors Influencing Metal Bioavailability in Soils: Preliminary Investigations for the Development of a Critical Loads Approach for Metals. Chemical Speciation and Bioavailability, 10, 61-75. https://doi.org/10.3184/095422998782775835 
[71] Rodríguez, L., Ruiz, E., Alonso-Azcárate, J. and Rincón, J. (2009) Heavy Metal Distribution and Chemical Speciation in Tailings and Soils around a Pb-Zn Mine in Spain. Journal of Environmental Management, 90, 1106-1116. https://doi.org/10.1016/j.jenvman.2008.04.007

[72] Wang, Z., Shan, X. and Zhang, S. (2002) Comparison between Fractionation and Bioavailability of Trace Elements in Rhizosphere and Bulk Soils. Chemosphere, 46, 1163-1171. https://doi.org/10.1016/S0045-6535(01)00206-5

[73] Tokalioğlu, Ş., Kartal, Ş. and Elçi, L. (2000) Determination of Heavy Metals and Their Speciation in Lake Sediments by Flame Atomic Absorption Spectrometry after a Four-Stage Sequential Extraction Procedure. Analytica Chimica Acta, 413, 33-40. https://doi.org/10.1016/S0003-2670(00)00726-1

[74] Omoyele, R.A. (2009) Development of a Mounted Cocoyam (Xanthosoma spp.) Harvester (Doctoral dissertation, Federal University of Technology Akure).

[75] Li, F.Y., Fan, Z.P., Xiao, P.F., Oh, K., Ma, X.P. and Hou, W. (2008) Contamination, Chemical Speciation and Vertical Distribution of Heavy Metals in Soils of an Old and Large Industrial Zone in Northeast China. Environmental Geology, 57, 1815-1823. https://doi.org/10.1007/s00254-008-1469-8

[76] Singh, M., Ansari, A.A., Muller, G. and Singh, I.B. (1997) Heavy Metals in Freshly Deposit Sediments of the Gomati River: A Tributary of Ganga River, Effect of $\mathrm{Hu}$ man Activities. Environmental Geology, 29, 246-252. https://doi.org/10.1007/s002540050123

[77] Mohammad Salah, E.A., Zaidan, T.A. and Al-Rawi, A.S. (2012) Assessment of Heavy Metals Pollution in the Sediments of Euphrates River, Iraq. Journal of Water Resource and Protection, 4, 1009-1023. https://doi.org/10.4236/jwarp.2012.412117

[78] Herrero Latorre, C., et al. (2012) Carbon Nanotubes as Solid-Phase Extraction Sorbents Prior to Atomic Spectrometric Determination of Metal Species: A Review. Analytica Chimica Acta, 749, 16-35. https://doi.org/10.1016/j.aca.2012.09.001

[79] Zhao, L., Xu, Y., Hou, H., Shangguan, Y. and Li, F. (2014) Source Identification and Health Risk Assessment of Metals in Urban Soils around the Tanggu Chemical Industrial District, Tianjin, China. Science of the Total Environment, 468-469, 654-662. https://doi.org/10.1016/j.scitotenv.2013.08.094

[80] Wang, L., Lu, X., Ren, C., Li, X. and Chen, C. (2014) Contamination Assessment and Health Risk of Heavy Metals in Dust from Changqing Industrial Park of Baoji, NW China. Environmental Earth Sciences, 71, 2095-2104. https://doi.org/10.1007/s12665-013-2613-7

[81] Olujimi, O.O., Oputu, O., Fatoki, O., Opatoyinbo, O.E., Aroyewun, O.A. and Baruani, J. (2015) Heavy Metals Speciation and Human Health Risk Assessment at an Illegal Gold Mining Site in Igun, Osun State, Nigeria. Journal of Health \& Pollution, 5, 19-32. https://doi.org/10.5696/i2156-9614-5-8.19

[82] Yang, Q., Chen, H. and Li, B. (2015) Source Identification and Health Risk Assessment of Metals in Indoor Dust in the Vicinity of Phosphorus Mining, Guizhou Province, China. Archives of Environmental Contamination and Toxicology, 68, 20-30. https://doi.org/10.1007/s00244-014-0064-0

[83] Ogunbanjo, O., Onawumi, O., Gbadamosi, M., Ogunlana, A. and Anselm, O. (2016) Chemical Speciation of Some Heavy Metals and Human Health Risk Assessment in Soil around Two Municipal Dumpsites in Sagamu, Ogun State, Nigeria. Chemical Speciation and Bioavailability, 28, 142-151. https://doi.org/10.1080/09542299.2016.1203267

[84] Shi, G., Chen, Z., Bi, C., Wang, L., Teng, J., Li, Y. and Xu, S. (2011) A Comparative 
Study of Health Risk of Potentially Toxic Metals in Urban and Suburban Road Dust in the Most Populated City of China. Atmospheric Environment, 45, 764-771. https://doi.org/10.1016/j.atmosenv.2010.08.039

[85] WHO (2004) The World Health Report 2004: Changing History. 96 p.

[86] Wagner, G.J. (1993) Accumulation of Cadmium in Crop Plants and Its Consequences to Human Health. Advances in Agronomy, 51, 173-212. https://doi.org/10.1016/S0065-2113(08)60593-3

[87] WHO (1993) Guidelines for Drinkingwater Quality, Recommendations. Vol. 1, 2nd Edition, World Health Organization, Geneva.

[88] Maihara, V.A. and Fávaro, D.I.T. (2006) Toxic Elements. In: Cozzolino, S.M.F., Ed., Bioavailability of Nutrients, Manole, Barueri, 629-660. (In Portuguese)

[89] Santos, E.E., Lauria, D.C. and Porto Da Silveira, C.L. (2004) Assessment of Daily Intake of Trace Elements Due to Consumption of Foodstuffs by Adult Inhabitants of Rio de Janeiro City. Science of the Total Environment, 327, 69-79. https://doi.org/10.1016/j.scitotenv.2004.01.016

[90] Kohlmeier, M. (2015) Nutrient Metabolism. Elsevier, Amsterdam. https://doi.org/10.1016/B978-0-12-387784-0.00003-1

[91] National Research Council (1989) Recommended Dietal Allowances. National Academic Press, Washington DC.

[92] Biego, G.H., Joyeux, M., Hartemann, P. and Debry, G. (1998) Daily Intake of Essential Minerals and Metallic Micropollutants from Foods in France. Science of the Total Environment, 217, 27-36. https://doi.org/10.1016/S0048-9697(98)00160-0

[93] Sridhara Chary, N., Kamala, C.T. and Samuel Suman Raj, D. (2008) Assessing Risk of Heavy Metals from Consuming Food Grown on Sewage Irrigated Soils and Food Chain Transfer. Ecotoxicology and Environmental Safety, 69, 513-524. https://doi.org/10.1016/j.ecoenv.2007.04.013

[94] Khan, S., Cao, Q., Zheng, Y.M., Huang, Y.Z. and Zhu, Y.G. (2008) Health Risks of Heavy Metals in Contaminated Soils and Food Crops Irrigated with Wastewater in Beijing, China. Environmental Pollution, 152, 686-692. https://doi.org/10.1016/j.envpol.2007.06.056

[95] Wang, X., Sato, T., Xing, B. and Tao, S. (2005) Health Risks of Heavy Metals to the General Public in Tianjin, China via Consumption of Vegetables and Fish. Science of the Total Environment, 350, 28-37. https://doi.org/10.1016/j.scitotenv.2004.09.044

[96] Huang, M., Zhou, S., Sun, B. and Zhao, Q. (2008) Heavy Metals in Wheat Grain: Assessment of Potential Health Risk for Inhabitants in Kunshan, China. Science of the Total Environment, 405, 54-61. https://doi.org/10.1016/j.scitotenv.2008.07.004

[97] Baird, C. (2002) Environmental Chemistry. Bookman, Porto Alegre, 157. (In Portuguese) 